\title{
Analisis Ketersediaan Fasilitas Sosial di Kabupaten Banjarnegara, sebagai Pendukung Kondisi Darurat Bencana dan Pengembangan Wilayah
}

\author{
Mohammad Isnaini Sadali, Fikri Intizhar, Aisyah
}

Masuk: 10112017 / Diterima: 30122017 / Dipublikasi: 31122017

(c) 2017 Fakultas Hukum dan IImu Sosial UNDIKSHA dan IGI

\begin{abstract}
The availability of social facilities in a region needs to be adjusted to the standard needs of regional public facilities to serve the needs of the population. Evaluation of the availability and needs of social facilities is important to support regional development. Besides that, social facilities can be an emergency infrastructure facility when disaster strikes. This research uses quantitative research method and analyzed descriptively. The aims of this research are: to identify and analyze the suitability between the availability and the need for social facilities in Banjarnegara Regency based on the serviceability, and to describe the benefits of social facilities for disaster emergency. The results of this study indicate that junior high school facilities still require additional in some districts and high school education facilities in Kabupaten Banjarnegara still require addition in all subdistrict, while health facility in the form of 'Puskesmas Pembantu' still needed addition of 1 facility in Kecamatan Purwareja Klampok. The existence of schools, health facilities and worship becomes very important when disaster occurs and requires rapid, appropriate, and emergency evacuation.
\end{abstract}

Key words: social facilities, infrastructure, disaster, regional development

\begin{abstract}
Abstrak
Ketersediaan fasilitas sosial pada suatu wilayah perlu disesuaikan dengan standar kebutuhan sarana parasana umum wilayah untuk melayani kebutuhan penduduk. Evaluasi ketersediaan dan kebutuhan fasilitas sosial penting dilakukan guna mendukung pengembangan wilayah. Di sisi lain, fasilitas sosial dapat menjadi sarana prasarana darurat pada saat terjadi bencana. Penelitian ini menggunakan metode penelitian kuantitatif dan dianalisis secara deskriptif. Tujuan dari penelitian ini adalah: mengidentifikasi dan menganalisis kesesuaian antara ketersediaan dengan kebutuhan fasilitas sosial di Kabupaten Banjarnegara berdasarkan daya layan, serta mendiskripsikan manfaat fasilitas sosial untuk darurat bencana. Hasil dari penelitian ini menunjukkan bahwa sarana pendidikan SMP masih memerlukan penambahan di beberapa kecamatan dan sarana pendidikan SMA di Kabupaten Banjarnegara masih memerlukan penambahan di seluruh kecamatan, sedangkan fasilitas kesehatan berupa Puskesmas Pembantu masih dibutuhkan penambahan 1 fasilitas di Kecamatan Purwareja Klampok. Keberadaan sekolah, sarana kesehatan dan peribadatan menjadi sangat penting ketika bencana terjadi dan membutuhkan evakuasi secara cepat, tepat, dan darurat.
\end{abstract}

Kata kunci : fasilitas sosial, sarana prasarana, bencana, pengembangan wilayah

\section{Pendahuluan}

Kebutuhan penduduk yang paling

Mohammad Isnaini Sadali

Progam Studi Pembangunan Wilayah, Fakultas Geografi

UGM. Bulaksumur, Sleman, Yogyakarta, 55281

m.isnaini.s@ugm.ac.id mendasar selain pangan dan sandang adalah tempat tinggal yang sering disebut dengan lahan permukiman (Sadali, 2014). Sarana prasarana permukiman sebagai penunjang 
kehidupan sosial, ekonomi dan budaya menjadi penting dalam pemenuhan kebutuhan hidup. Kebutuhan lahan permukiman akan terus meningkat dengan diikuti oleh kebutuhan sarana prasarana umum pendukung lainnya seiring perkembangan penduduk pada suatu wilayah. Perkembangan penduduk dapat dilihat melalui pertambahan penduduk yang pada dasarnya dipengaruhi oleh beberapa faktor demografi, yaitu: kematian (mortalitas), kelahiran (natalitas), dan migrasi (mobilitas). Kecenderungan perkembangan penduduk yang terjadi di Indonesia secara umum dan di Kabupaten Banjarnegara saat ini adalah populasi penduduk akan cenderung mengelompok dan banyak pada wilayah perkotaan atau pusat kegiatan tertentu. Menurut Yunus (2002) daerah pusat kegiatan merupakan pusat kehidupan sosial, ekonomi, budaya, dan politik dalam suatu kota sehingga pada kawasan ini terdapat bangunan utama untuk kegiatan sosial ekonomi. Pusat kegiatan pada suatu wilayah mampu memberikan daya tarik bagi beberapa penduduk yang memang memiliki kepentingan dan motif tertentu dengan harapan dapat diwujudkan pada daerah tujuan.

Lingkungan permukiman merupakan sebuah kawasan perumahan dengan luas dan jumlah penduduk tertentu yang dilengkapi dengan sistem sarana prasarana lingkungan melalui penataan yang terencana dan teratur sehingga memungkinkan pengelolaan dan pelayanan yang optimal. Fasilitas sosial yang termasuk dalam sarana prasarana umum yang dibutuhkan masyarakat dalam suatu wilayah meliputi sarana pendidikan, kesehatan, perdagangan dan jasa, pemerintahan dan pelayanan umum, peribadatan, rekreasi dan kebudayaan, olahraga dan lapangan terbuka, Ruang Terbuka Hijau (RTH) dan makam serta sarana prasarana penunjang kegiatan sosial lainnya di wilayah tertentu. Ketersediaan fasilitas sosial pada suatu wilayah perlu disesuaikan dengan standar kebutuhan sarana parasana umum untuk melayani penduduk yang berada pada wilayah tersebut. Sarana prasarana umum berfungsi untuk mengembangkan kehidupan dan penghidupan keluarga serta mengembangkan kegiatan bermasyarakat terkait sosial, budaya dan ekonomi. Evaluasi ketersediaan dan kebutuhan fasilitas sosial penting dilakukan guna mendukung pengembangan wilayah. Hal ini terkait daya layan fasilitas sosial terhadap jumlah penduduk yang dilayani apakah sudah dapat dipenuhi atau diperlukan penambahan lagi.

Pengembangan suatu wilayah sebagai sebuah pusat kegiatan akan berorientasi pada penyediaan sarana prasarana atau fasilitas penunjang yang ada di dalamnya mampu mendukung perkembangan kegiatan wilayah tersebut. Pemenuhan kebutuhan fasilitas pelayanan masyarakat oleh Pemerintah Kabupaten Banjarnegara ditujukan untuk menjamin kesejahteraan dan keberlangsungan hidup masyarakat yang tinggal di setiap bagian wilayah di Kabupaten Banjarnegara. Keberadaan fasilitas sosial sebagai sarana prasarana umum wilayah seperti sarana pendidikan, sarana kesehatan, sarana ruang 
terbuka dan lapangan olahraga merupakan penunjang bagi keberadaan sebuah kawasan perumahan dan permukiman. Di sisi lain, fasilitas sosial dapat menjadi sarana prasarana darurat pada saat terjadi bencana. Keberadaan sekolah, sarana kesehatan, sarana peribadatan, gedung atau balai pertemuan menjadi sangat penting ketika bencana terjadi dan membutuhkan evakuasi secara cepat, tepat, dan darurat. Penyiapan sarana prasarana umum sebagai bentuk layanan tanggap darurat merupakan respon cepat evakuasi dan antisipasi korban bencana.

Indonesia termasuk wilayah yang dikelilingi oleh dua jalur gunung berapi (sirkum Meditterrania dan sirkum Pasifik), sehingga negara Indonesia rentan terhadap berbagai bencana alam (Suarna, 2013). Kabupaten Banjarnegara termasuk wilayah yang dilewati jalur gunung berapi sirkum Meditterrania. Menurut peta indeks rawan bencana nasional tahun 2012 yang dikeluarkan BNPB, Kabupaten Banjarnegara termasuk wilayah yang memiliki tingkat kerawanan bencana tinggi. Frekuensi kejadian bencana dari Januari 2014-Juni 2014 mencapai lebih dari 7 kali. Dengan demikian kesiapsiagaan masyarakat dan sarana prasarana pendukung mitigasi bencana di Kabupaten Banjarnegara perlu disiapkan sedini mungkin.

Berdasarkan penjelasan di atas maka perlu diteliti tentang ketersediaan fasilitas sosial di Kabupaten Banjarnegara, sebagai pendukung kondisi darurat bencana dan pengembangan wilayah. Tujuan dilaksanakannya penelitian ini ditekankan pada beberapa hal, yaitu:

1. Mengidentifikasi ketersediaan fasilitas sosial di Kabupaten Banjarnegara;

2. Menganalisis kesesuaian antara ketersediaan dan kebutuhan fasilitas sosial di Kabupaten Banjarnegara berdasarkan daya layan; dan

3. Mendiskripsikan manfaat fasilitas sosial sebagai sarana prasarana umum untuk darurat bencana.

\section{Metode}

Penelitian ini menggunakan metode penelitian kuantitatif dengan data sekunder sebagai data utama dan dianalisis secara deskriptif. Lokasi penelitian berada di seluruh Kabupaten Banjarnegara yang terdiri dari 20 kecamatan. Pengolahan data dilakukan dengan mengacu pada Peraturan Menteri PU No. 41/PRT/M/2007 tentang Pedoman Kriteria Teknis Kawasan Budidaya dan SNI 03-17332004 tentang Tata Cara Perencanaan Lingkungan Perumahan di Perkotaan. Ketersediaan sarana prasarana umum yang sudah ada di Kabupaten Banjarnegara dapat dievaluasi jumlah (kuantitas) sarana prasarana umum dengan standar kebutuhan sarana prasarana umum pada suatu wilayah. Pada prinsipnya kebutuhan fasilitas sosial didasarkan pada daya layan atau kemampuan sarana prasarana melayani penduduk yang berada di wiiayah tersebut. Dengan demikian kebutuhan dan ketersediaan sarana prasarana umum di Kabupaten Banjarnegara diharapkan mampu melayani jumlah penduduk yang tinggal sesuai dengan standar yang sudah 
ditetapkan secara nasional. Pada penelitian ini, analisis ketersediaan dan kebutuhan sarana prasarana umum ditekankan pada 3 sarana utama, yaitu sarana pendidikan dan pembelajaran, kesehatan, serta peribadatan. Kebutuhan sarana prasarana umum (jumlah sarana dan luas lahan yang dibutuhkan) dirinci dalam Tabel 1 berikut ini.

Tabel 1.

Kebutuhan Sarana Pendidikan dan Pembelajaran, Kesehatan, serta Peribadatan

\begin{tabular}{|c|c|c|c|c|c|}
\hline \multirow[b]{2}{*}{ No. } & \multirow[b]{2}{*}{ Jenis Sarana } & \multirow{2}{*}{$\begin{array}{c}\text { Jumlah } \\
\text { Penduduk } \\
\text { Pendukung (jiwa) } \\
\end{array}$} & \multicolumn{2}{|c|}{ Kebutuhan Per Satuan Sarana } & \multirow{2}{*}{$\begin{array}{l}\text { Standard } \\
\left(\mathrm{m}^{2} / \mathrm{jiwa}\right)\end{array}$} \\
\hline & & & $\begin{array}{c}\text { Luas Lantai } \\
\text { Min. }\left(\mathrm{m}^{2}\right)\end{array}$ & $\begin{array}{l}\text { Luas Lahan } \\
\text { Min. }\left(\mathrm{m}^{2}\right) \\
\end{array}$ & \\
\hline \multicolumn{6}{|c|}{ Kebutuhan Sarana Pendidikan dan Pembelajaran } \\
\hline 1. & $\begin{array}{l}\text { Taman Kanak- } \\
\text { Kanak }\end{array}$ & 1.250 & 216 & 500 & 0,28 \\
\hline 2. & Sekolah Dasar & 1.600 & 633 & 2.000 & 1,25 \\
\hline 3. & SLTP & 4.800 & 2.282 & 9.000 & 1,88 \\
\hline 4. & SMU & 4.800 & 3.835 & 12.500 & 2,6 \\
\hline 5. & Taman Bacaan & 2.500 & 72 & 150 & 0,09 \\
\hline \multicolumn{6}{|c|}{ Kebutuhan Sarana Kesehatan } \\
\hline 1. & Posyandu & 1.250 & 36 & 60 & 0,048 \\
\hline 2. & $\begin{array}{l}\text { Balai Pangobatan } \\
\text { Warga }\end{array}$ & 2.500 & 150 & 300 & 0,12 \\
\hline 3. & $\begin{array}{l}\text { BKIA/Klinik } \\
\text { Bersalin } \\
\end{array}$ & 30.000 & 1.500 & 3.000 & 0,1 \\
\hline 4. & $\begin{array}{l}\text { Puskesmas } \\
\text { Pembantu dan } \\
\text { Balai Pangobatan } \\
\text { Lingkungan }\end{array}$ & 30.000 & 150 & 300 & 0,006 \\
\hline 5. & $\begin{array}{l}\text { Puskesmas dan } \\
\text { Balai Pangobatan }\end{array}$ & 120.000 & 420 & 1000 & 0,008 \\
\hline 6. & $\begin{array}{l}\text { Tampat Praktek } \\
\text { Dokter }\end{array}$ & 5.000 & 18 & - & - \\
\hline 7. & $\begin{array}{l}\text { Apotik/ Rumah } \\
\text { Obat }\end{array}$ & 30.000 & 120 & 250 & 0,025 \\
\hline \multicolumn{6}{|c|}{ Kebutuhan Sarana Peribadatan } \\
\hline 1. & Musholla/ Langgar & 250 & 45 & 100 & 0,36 \\
\hline 2. & Masjid Warga & 2.500 & 300 & 600 & 0,24 \\
\hline 3. & $\begin{array}{l}\text { Masjid Lingkungan } \\
\text { (Kelurahan) }\end{array}$ & 30.000 & 1.800 & 3.600 & 0,12 \\
\hline 4. & Masjid Kecamatan & 120.000 & 3.600 & 5.400 & 0,03 \\
\hline 5. & $\begin{array}{l}\text { Sarana ibadah } \\
\text { agama lain }\end{array}$ & $\begin{array}{l}\text { Tergantung sistem } \\
\text { kekerabatan/ } \\
\text { Hirarki lembaga }\end{array}$ & $\begin{array}{l}\text { Tergantung } \\
\text { kebiasaan } \\
\text { setempat }\end{array}$ & $\begin{array}{l}\text { Tergantung } \\
\text { kebiasaan } \\
\text { setempat }\end{array}$ & - \\
\hline
\end{tabular}

Sumber: SNI 03-1733-2004

\section{Hasil dan Pembahasan}

\subsection{Ketersediaan Fasilitas Sosial}

Jumlah dan distribusi ketersediaan fasilitas sosial di Kabupaten
Banjarnegara memiliki variasi pada setiap kecamatan, dan hal ini menjadi salah satu pertimbangan dalam penentuan hierarki wilayah. Di dalam 


dokumen RTRW Kabupaten
Banjarnegara tahun 2011-2030,
Kecamatan Banjarnegara memiliki
status sebagai Pusat Kegiatan Lokal
(PKL) dan merupakan wilayah
pengembangan I. Adanya prioritas
pengembangan tersebut berdampak
positif terhadap jumlah dan
kelengkapan sarana prasarana yang
tersedia untuk melayani penduduk
setempat dan penduduk yang ada di
daerah pelayanan (Roswita, 2016).
Senada dengan hasil penelitian Ardila
(2012), Kecamatan Banjarnegara
merupakan pusat pertumbuhan yang
berada pada hierarki 1, sehingga
fasilitas pelayanan di kecamatan ini
lebih lengkap dan berkembang
dibandingkan kecamatan lainnya.

\section{Pendidikan}

Kabupaten Banjarnegara pada tahun 2015 tercatat memiliki 459 sekolah playgroup, 4 Taman Kanan-Kanak (TK) Negeri dan 294 TK swasta, 636 Sekolah Dasar (SD) Negeri dan 13 swasta, 4 Madrasan Ibtidaiyah (MI) Negeri dan 197 swasta, 85 Sekolah Menengah Pertama (SMP) Negeri dan 22 swasta, 2 Madrasan Tsanawiyah (MTs) negeri dan 33 swasta, 8 Sekolah Menengah Atas (SMA) Negeri dan 5 swasta, 2 Madrasan Aliyah (MA) Negeri dan 13 swasta, 6 Sekolah Menengah Kejuruan (SMK) Negeri dan 16 swasta, serta 140 Pondok Pesantren. Total keseluruhan fasilitas pendidikan yang ada mencapai 1.941 pada tahun 2014, angka ini cenderung menurun dari tahun 2012 yang mencapai 1.998 fasilitas. Penurunan jumlah fasilitas pendidikan tejadi pada fasilitas playgroup, Ml, dan SMK di beberapa kecamatan.

\section{Kesehatan}

Kabupaten Banjarnegara memiliki 173 fasilitas pelayanan kesehatan di tahun 2015. Pembangunan fasilitas pelayanan kesehatan relatif meningkat dari tahun sebelumnya yang hanya berjumlah 168 fasilitas di tahun 2014 . Beberapa jenis pelayanan kesehatan tersebut diantaranya: rumah sakit, klinik, puskesmas, puskesmas pembantu, puskesmas keliling, toko obat, laboratorium, dan apotek. Di Kabupaten Banjarnegara terdapat 3 rumah sakit yang terdiri dari 1 rumah sakit negeri dan 2 rumah sakit swasta, 7 klinik swasta, 35 puskesmas, 41 puskesmas pembantu, 35 puskesmas keliling, 10 toko obat, 1 laboratorium kesehatan, dan 41 apotek. Dari segi jumlah dan jenis, konsentrasi pelayanan kesehatan terletak di Kecamatan Banjarnegara sebagai ibukota kecamatan dengan total jumlah fasilitas kesehatan mencapai 25 fasilitas, termasuk di dalamnya laboratorium kesehatan.

\section{Tempat Ibadah}

Sebagai salah satu penunjang kegiatan keagamaan, fasilitas tempat ibadah merupakan bagian yang penting. $\mathrm{Di}$ Kabupaten Banjarnegara pada tahun 2015 terdapat 5.202 jumlah tempat ibadah dengan rincian 1.533 masjid, 3.634 musholla/langgar, 9 gereja katolik, 18 gereja protestan, dan 8 vihara/pura, Jumlah ini cenderung berkurang dari tahun 2014 yang memiliki 5.272 jumlah tempat ibadah dengan rincian 1.532 masjid, 3.705 langgar/musholla, 9 gereja katolik, 18 gereja protestan, dan 8 vihara/pura. Jumlah tempat ibadah yang berkurang pada data tahun 2015 ini erat hubungannya dengan kejadian 
bencana alam berupa longsor dasyat tahun 2014 yang menimbulkan korban jiwa dan kerusakan pada sejumlah rumah dan fasilitas umum. Kejadian tersebut menimpa 2 kecamatan, yaitu Karangkobar dan Madukara (Humas DPRD Banjarnegara, 2014).

\subsection{Analisis Kesesuaian dan Daya Layan Fasilitas Sosial \\ Fasilitas Pendidikan}

Ditinjau dari kuantitasnya, fasilitas pendidikan memiliki standar yang berbeda-beda. Taman Kanak-Kanak (TK) memiliki standar 1 fasilitas TK untuk melayani 1.250 penduduk. Fasilitas SD dan Ml, setiap terdapat 1.600 penduduk maka minimal didirikan 1 SD/MI. Untuk tingkat SMP/Mts, minimal terdapat 1 fasilitas apabila untuk 4.800 penduduk. Sedangkan untuk tingkat SMA/MA/SMK, setiap terdapat 4.800 penduduk maka minimal didirikan 1 fasilitas pendidikan setingkat SMA sederajat.

Berdasarkan Tabel 2, fasilitas pendidikan TK di beberapa kecamatan, belum semuanya memenuhi standar yang ada. Namun secara keseluruhan dari kondisi eksisting yang ada, fasilitas TK di Kabupaten Banjarnegara (sejumlah 757 TK) sudah dapat memenuhi kebutuhan penduduk (sejumlah 712 TK). Kecamatan Rakit sebagai kecamatan yang memiliki fasilitas pendidikan berupa TK terbanyak (59 unit) dan memenuhi jumlah standar yang ditetapkan. Hasil analisis daya layan yang telah dilakukan menunjukkan bahwa terdapat 8 kecamatan (dari 20 kecamatan) yang belum memenuhi kebutuhan fasilitas pendidikan berupa TK, antara lain:
Kecamatan Mandiraja, Purwanegara, Wanadadi, Punggelan, Karangkobar, Pejawaran, Batur, dan Kalibening (lihat Tabel 2). Meskipun demikian pada setiap kecamatan sudah memiliki fasilitas pendidikan berupa TK dengan jumlah yang bervariasi. Berdasarkan selisih antara ketersediaan dan kebutuhan TK di Kabupaten Banjarnegara, di Kecamatan Kalibening masih memerlukan jumlah TK paling banyak, yaitu 13 penambahan. Kecamatan lain yang membutuhkan penambahan jumlah TK cukup banyak adalah Kecamatan Punggelan dan Kecamatan Batur dengan jumlah penambahan yang dibutuhkan sebanyak 9 TK.

Jumlah SD/MI di Kabupaten Banjarnegara pada tahun 2015 seluruhnya berjumlah 850 fasilitas. Kecamatan Punggelan menjadi kecamatan dengan jumlah total SD dan MI terbanyak yaitu 70 fasilitas, sedangkan Kecamatan Pandanarum menjadi kecamatan dengan jumlah fasilitas SD/MI yang paling sedikit yaitu berjumlah 23 fasilitas. Dengan standar 1.600 penduduk untuk 1 fasilitas SD/MI, seluruh Kecamatan di Kabupaten Banjarnegara telah memenuhi standar yang ditetapkan. Dengan demikian kebutuhan penambahan fasilitas SD/MI di Kabupaten Banjarnegara tidak diperlukan, sehingga dapat difokuskan pada peningkatan kualitas sumberdaya (siswa, tenaga pendidik, dan tenaga kependidikan) serta sarana prasarana penunjang pada pendidikan SD/MI sederajat.

Berdasarkan Tabel 2, Jumlah SMP/Mts di Kabupaten Banjarnegara pada tahun 2015 seluruhnya berjumlah 144 
fasilitas. Jumlah fasilitas pendidikan yang sudah ada belum dapat memenuhi standar kebutuhan fasilitas pendidikan SMP/sederajat pada sebagian kecamatan di Kabupaten Banjarnegara. Sejumlah 13 kecamatan belum mencukupi standar jumlah fasilitas pendidikan yang sudah ditetapkan oleh Kementerian Pekerjaan Umum (SNI 03-1733-2004). Kecamatan yang sudah mencukupi standar jumlah fasilitas pendidikan atau tidak memerlukan lagi penambahan fasilitas pendidikan berupa SMP/sederajat antara lain: Kecamatan Banjarnegara,
Pagedongan, Madukara, Wanadadi, Karangkobar, Kalibening, dan Pandanarum. Secara keseluruhan, jumlah fasilitas pendidikan berupa SMP/sederajat di Kabupaten Banjarnegara saat ini (144 sekolah), belum dapat memenuhi kebutuhan penduduk terhadap fasilitas pendidikan SMP/sederajat (185 sekolah). Hasil pengolahan data menunjukkan bahwa jumlah fasilitas pendidikan SMP/sederajat di Kabupaten Banjarnegara masih memerlukan penambahan sebanyak 41 sekolah.

\section{PETA KETERSEDIAAN FASILITAS PENDIDIKAN KABUPATEN BANJARNEGERA}

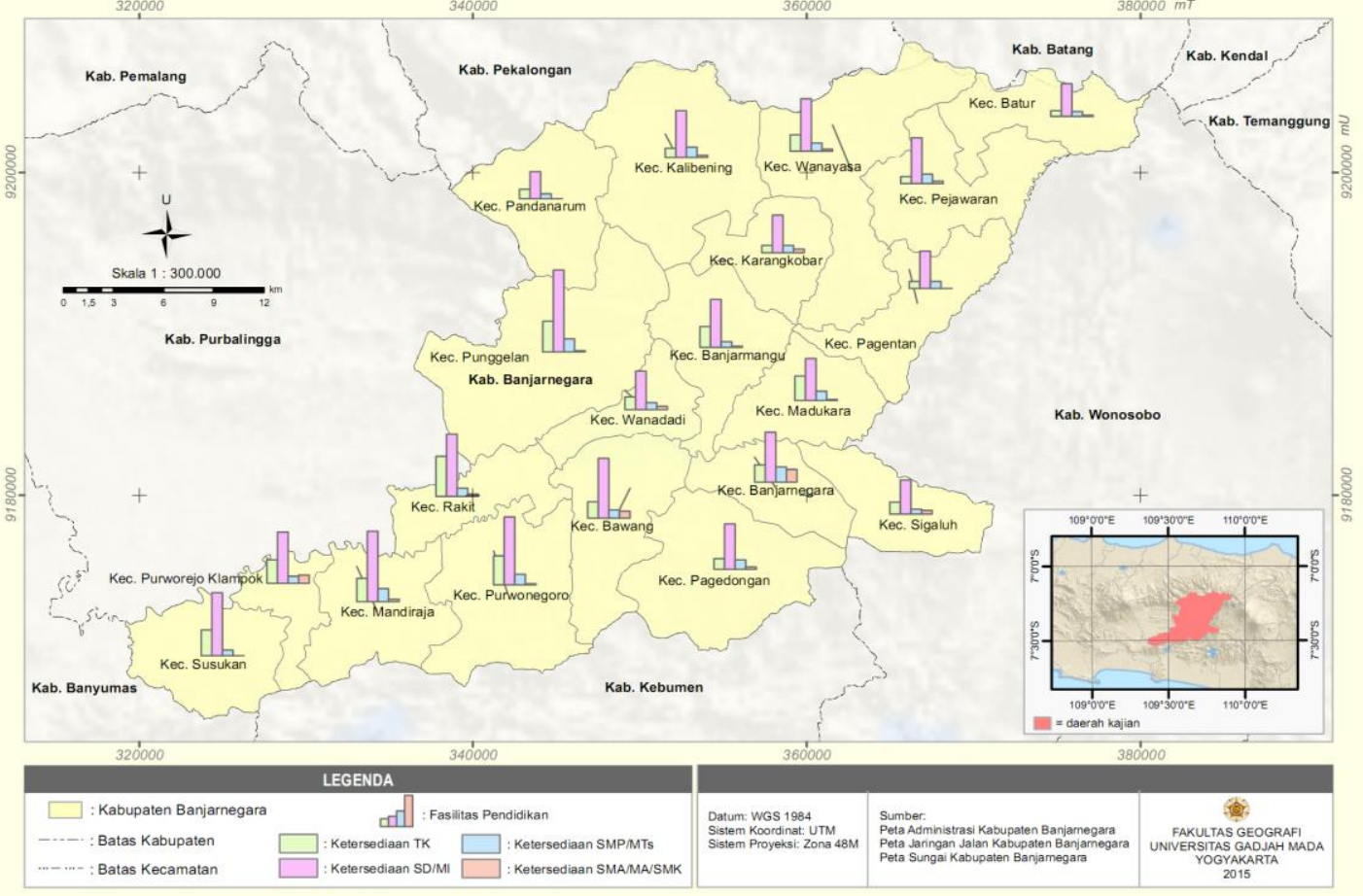

Gambar 1. Ketersediaan Fasilitas Pendidikan Kabupaten Banjarnegara

Jumlah fasilitas pendidikan pada strata Sekolah Menengah Atas atau sederajat di Kabupaten Banjarnegara hanya berjumlah 50 fasilitas. Jumlah ini dapat dikatakan sedikit, melihat jumlah total penduduk yang ada di Kabupaten
Banjarnegara mencapai 889.951 jiwa (lihat Tabel 2). Apabila menunggunakan standar yang sudah ditetapkan yaitu 4.800 penduduk untuk setiap 1 fasilitas SMA/sederajat, maka di seluruh kecamatan di Kabupaten 
Banjarnegara tidak ada yang memenuhi syarat. Mempertimbangkan jumlah fasilitas pendidikan SMA/sederajat dan persebarannya di Kabupaten Banjarnegara, maka ke depan penambahan jumlah SMA/sederajat dapat diarahkan pada kecamatan yang belum memiliki fasilitas pendidikan SMA/sederajat seperti Kecamatan Susukan, Pagentan, dan Pandanarum. Hal ini mempertimbangkan kebutuhan penduduk (population threshold) di Kabupaten Banjarnegara terhadap fasilitas pendidikan berupa SMA/sederajat. Dengan kata lain, terdapat kemungkinan sebagian penduduk yang akan bersekolah SMA/sederajat melakukan migrasi keluar Kabupaten Banjarnegara karena tidak dapat terakomodir atau kuota di Kabupaten Banjarnegara sudah tidak dapat memenuhi.

Tabel 2.

Ketersediaan dan Kebutuhan Fasilitas Pendidikan di Kabupaten Banjarnegara Tahun 2015

\begin{tabular}{|c|c|c|c|c|c|c|c|c|}
\hline No & $\begin{array}{c}\text { Kecama- } \\
\text { tan }\end{array}$ & $\begin{array}{c}\text { Jumlah } \\
\text { Pendu- } \\
\text { duk } \\
2015\end{array}$ & $\begin{array}{c}\text { Keter- } \\
\text { sediaan } \\
\text { TK }\end{array}$ & $\begin{array}{l}\text { Kebutuhan } \\
\text { TK (1:1.250 } \\
\text { org) }\end{array}$ & $\begin{array}{l}\text { Ket. } \\
\text { TK }\end{array}$ & $\begin{array}{l}\text { Keter- } \\
\text { sediaan } \\
\text { SD }\end{array}$ & $\begin{array}{c}\text { Kebutu- } \\
\text { han SD } \\
(1: 1.600 \\
\text { org) }\end{array}$ & $\begin{array}{l}\text { Ket. } \\
\text { SD }\end{array}$ \\
\hline 1 & Susukan & 59.621 & 52 & 48 & $\mathrm{~T}$ & 54 & 37 & $\mathrm{~T}$ \\
\hline 2 & $\begin{array}{l}\text { Purwareja } \\
\text { Klampok }\end{array}$ & 46.139 & 47 & 37 & $\mathrm{~T}$ & 44 & 29 & $\mathrm{~T}$ \\
\hline 3 & Mandiraja & 63.835 & 45 & 51 & $\mathrm{~B} \mathrm{~T}$ & 60 & 40 & $\mathrm{~T}$ \\
\hline 4 & $\begin{array}{l}\text { Purwa- } \\
\text { negara }\end{array}$ & 69.401 & 49 & 56 & B T & 58 & 43 & $\mathrm{~T}$ \\
\hline 5 & Bawang & 52.078 & 50 & 42 & $\mathrm{~T}$ & 51 & 33 & $\mathrm{~T}$ \\
\hline 6 & $\begin{array}{l}\text { Banjar- } \\
\text { negara }\end{array}$ & 57.849 & 49 & 46 & $\mathrm{~T}$ & 43 & 36 & $\mathrm{~T}$ \\
\hline 7 & $\begin{array}{l}\text { Pagedo- } \\
\text { ngan }\end{array}$ & 35.099 & 34 & 28 & $\mathrm{~T}$ & 39 & 22 & $\mathrm{~T}$ \\
\hline 8 & Sigaluh & 29.206 & 41 & 23 & $\mathrm{~T}$ & 29 & 18 & $\mathrm{~T}$ \\
\hline 9 & Madukara & 40.496 & 49 & 32 & $\mathrm{~T}$ & 36 & 25 & $T$ \\
\hline 10 & $\begin{array}{l}\text { Banjar- } \\
\text { mangu }\end{array}$ & 39.300 & 40 & 31 & $\mathrm{~T}$ & 41 & 25 & $\mathrm{~T}$ \\
\hline 11 & Wanadadi & 28.440 & 21 & 23 & B T & 33 & 18 & $\mathrm{~T}$ \\
\hline 12 & Rakit & 49.346 & 59 & 39 & $\mathrm{~T}$ & 53 & 31 & $\mathrm{~T}$ \\
\hline 13 & $\begin{array}{l}\text { Pungge- } \\
\text { lan }\end{array}$ & 69.352 & 46 & 55 & B T & 70 & 43 & $\mathrm{~T}$ \\
\hline 14 & $\begin{array}{l}\text { Karang- } \\
\text { kobar }\end{array}$ & 27.562 & 19 & 22 & B T & 32 & 17 & $\mathrm{~T}$ \\
\hline 15 & Pagentan & 35.569 & 31 & 28 & $\mathrm{~T}$ & 32 & 22 & $T$ \\
\hline 16 & $\begin{array}{l}\text { Pejawa- } \\
\text { ran }\end{array}$ & 41.205 & 27 & 33 & B T & 39 & 26 & $\mathrm{~T}$ \\
\hline 17 & Batur & 36.912 & 21 & 30 & B T & 28 & 23 & $\mathrm{~T}$ \\
\hline 18 & $\begin{array}{l}\text { Wanayas } \\
\text { a }\end{array}$ & 44.336 & 36 & 35 & $\mathrm{~T}$ & 45 & 28 & $\mathrm{~T}$ \\
\hline 19 & $\begin{array}{l}\text { Kali- } \\
\text { bening }\end{array}$ & 43.144 & 22 & 35 & B T & 40 & 27 & $\mathrm{~T}$ \\
\hline 20 & $\begin{array}{l}\text { Pandan- } \\
\text { arum }\end{array}$ & 21.061 & 19 & 17 & $\mathrm{~T}$ & 23 & 13 & $\mathrm{~T}$ \\
\hline
\end{tabular}




\begin{tabular}{|c|c|c|c|c|c|c|c|c|}
\hline & Jumlah & 889.951 & 757 & 712 & $\mathrm{~T}$ & 850 & 556 & $\mathbf{T}$ \\
\hline No & $\begin{array}{l}\text { Kecama- } \\
\tan \end{array}$ & $\begin{array}{c}\text { Jumlah } \\
\text { Pend- } \\
\text { uduk } \\
2015\end{array}$ & $\begin{array}{l}\text { Keter- } \\
\text { sediaan } \\
\text { SMP }\end{array}$ & $\begin{array}{c}\text { Kebutuhan } \\
\text { SMP (1:4.800 } \\
\text { org) }\end{array}$ & $\begin{array}{l}\text { Ket. } \\
\text { SMP }\end{array}$ & $\begin{array}{l}\text { Keter- } \\
\text { sediaan } \\
\text { SMA }\end{array}$ & $\begin{array}{c}\text { Kebutu- } \\
\text { han SMA } \\
(1: 4.800 \\
\text { org })\end{array}$ & $\begin{array}{l}\text { Ket. } \\
\text { SMA }\end{array}$ \\
\hline 1 & Susukan & 59.621 & 5 & 12 & $\overline{\mathrm{B} \text { T }}$ & 0 & 12 & $\overline{\mathrm{B} \mathrm{T}}$ \\
\hline 2 & $\begin{array}{l}\text { Purwareja } \\
\text { Klampok }\end{array}$ & 46.139 & 6 & 10 & B T & 7 & 10 & B T \\
\hline 3 & Mandiraja & 63.835 & 11 & 13 & B T & 2 & 13 & B T \\
\hline 4 & $\begin{array}{l}\text { Purwa- } \\
\text { negara }\end{array}$ & 69.401 & 9 & 14 & B T & 1 & 14 & B T \\
\hline 5 & Bawang & 52.078 & 7 & 11 & $\mathrm{~B} \mathrm{~T}$ & 6 & 11 & $\mathrm{~B} \mathrm{~T}$ \\
\hline 6 & $\begin{array}{l}\text { Banjar- } \\
\text { negara }\end{array}$ & 57.849 & 13 & 12 & $\mathrm{~T}$ & 11 & 12 & B T \\
\hline 7 & $\begin{array}{l}\text { Pagedo- } \\
\text { ngan }\end{array}$ & 35.099 & 8 & 7 & $\mathrm{~T}$ & 2 & 7 & $\mathrm{~B} T$ \\
\hline 8 & Sigaluh & 29.206 & 4 & 6 & B T & 3 & 6 & $\mathrm{~B} \mathrm{~T}$ \\
\hline 9 & Madukara & 40.496 & 8 & 8 & $T$ & 1 & 8 & B T \\
\hline 10 & $\begin{array}{l}\text { Banjar- } \\
\text { mangu }\end{array}$ & 39.300 & 5 & 8 & B T & 1 & 8 & B T \\
\hline 11 & Wanadadi & 28.440 & 6 & 6 & $T$ & 3 & 6 & B T \\
\hline 12 & Rakit & 49.346 & 7 & 10 & B T & 2 & 10 & B T \\
\hline 13 & $\begin{array}{l}\text { Pungge- } \\
\text { lan }\end{array}$ & 69.352 & 11 & 14 & B T & 1 & 14 & B T \\
\hline 14 & $\begin{array}{l}\text { Karang- } \\
\text { kobar }\end{array}$ & 27.562 & 6 & 6 & $\mathrm{~T}$ & 3 & 6 & B T \\
\hline 15 & Pagentan & 35.569 & 6 & 7 & B T & 0 & 7 & B T \\
\hline 16 & $\begin{array}{l}\text { Pejawa- } \\
\text { ran }\end{array}$ & 41.205 & 8 & 9 & B T & 2 & 9 & B T \\
\hline 17 & Batur & 36.912 & 4 & 8 & $\mathrm{~B} \mathrm{~T}$ & 1 & 8 & B T \\
\hline 18 & $\begin{array}{l}\text { Wana- } \\
\text { yasa }\end{array}$ & 44.336 & 7 & 9 & B T & 2 & 9 & B T \\
\hline 19 & $\begin{array}{l}\text { Kali- } \\
\text { bening }\end{array}$ & 43.144 & 9 & 9 & $\mathrm{~T}$ & 2 & 9 & B T \\
\hline \multirow[t]{2}{*}{20} & $\begin{array}{l}\text { Pandan- } \\
\text { arum }\end{array}$ & 21.061 & 4 & 4 & $\mathrm{~T}$ & 0 & 4 & B T \\
\hline & Jumlah & 889.951 & 144 & 185 & B T & 50 & 185 & B T \\
\hline
\end{tabular}

Sumber: Hasil pengolahan dan analisis data primer, 2017

\section{Kesehatan}

Fasilitas kesehatan merupakan hal yang vital di setiap kondisi, utamanya saat terjadi bencana. Banyaknya jumlah fasilitas kesehatan dapat pula menggambarkan kondisi ketahanan masyarakat yang ada. Fasilitas kesehatan dibagi menjadi beberapa tingkatan sesuai dengan kapasitasnya, diantaranya rumah sakit, klinik, puskesmas, puskesmas pembantu, dan fasilitas-fasilitas pendukung seperti puskesmas keliling, laboratorium, apotek, dan toko obat.

Rumah sakit merupakan fasilitas kesehatan dengan kapasitas jumlah pasien terbesar. Berdasarkan standar yang ada (SNI 03-1733-2004), keberadaan 1 fasilitas rumah sakit dapat melayani sekurang-kurangnya 240.000 penduduk. Di Kabupaten 
Banjarnegara terdapat 3 rumah sakit, dengan kebutuhan rumah sakit sebanyak 7 rumah sakit. Jumlah ini belum dapat memenuhi kebutuhan sesuai standar yang telah ditetapkan Kementerian Pekerjaan Umum. Berdasarkan Tabel 3, dari 20 kecamatan yang ada di Kabupaten Banjarnegara hanya Kecamatan Bawang, Banjarnegara, dan Sigaluh saja yang sudah terdapat rumah sakit. Dengan kata lain kecamatankecamatan tersebut sudah memenuhi standar kebutuhan fasilitas kesehatan berupa rumah sakit.

Puskesmas merupakan fasilitas pendukung klinik dan rumah sakit. Menurut SNI 03-1733-2004, sebuah fasilitas puskesmas harus ada apabila terdapat 120.000 penduduk di sekitar daerah tersebut. Di Kabupaten Banjarnegara dari 20 kecamatan yang ada, kebutuhan penduduk terhadap fasilitas kesehatan berupa Puskesmas dapat dikatakan sudah terpenuhi. Secara keseluruhan terdapat 35 Puskesmas yang tersebar di seluruh kecamatan di Kabupaten Banjarnegara (lihat Gambar 2)

Puskesmas pembantu merupakan fasilitas pendukung puskesmas. Sebuah fasilitas puskesmas pembantu harus tersedia apabila sudah terdapat 30.000 penduduk disekitar lokasi tersebut (mengacu SNI 03-1733-2004). Pada Tabel 3 ditunjukkan bahwa dari 20 kecamatan yang ada di Kabupaten Banjarnegara terdapat 1 kecamatan yang belum memenuhi standar ini, yaitu Kecamatan Purwareja Klampok. Berdasarkan jumlah penduduk di Kabupaten Banjarnegara, kebutuhan Puskesmas Pembantu secara keseluruhan sudah terpenuhi.

\section{PETA KETERSEDIAAN FASILITAS KESEHATAN KABUPATEN BANJARNEGERA}

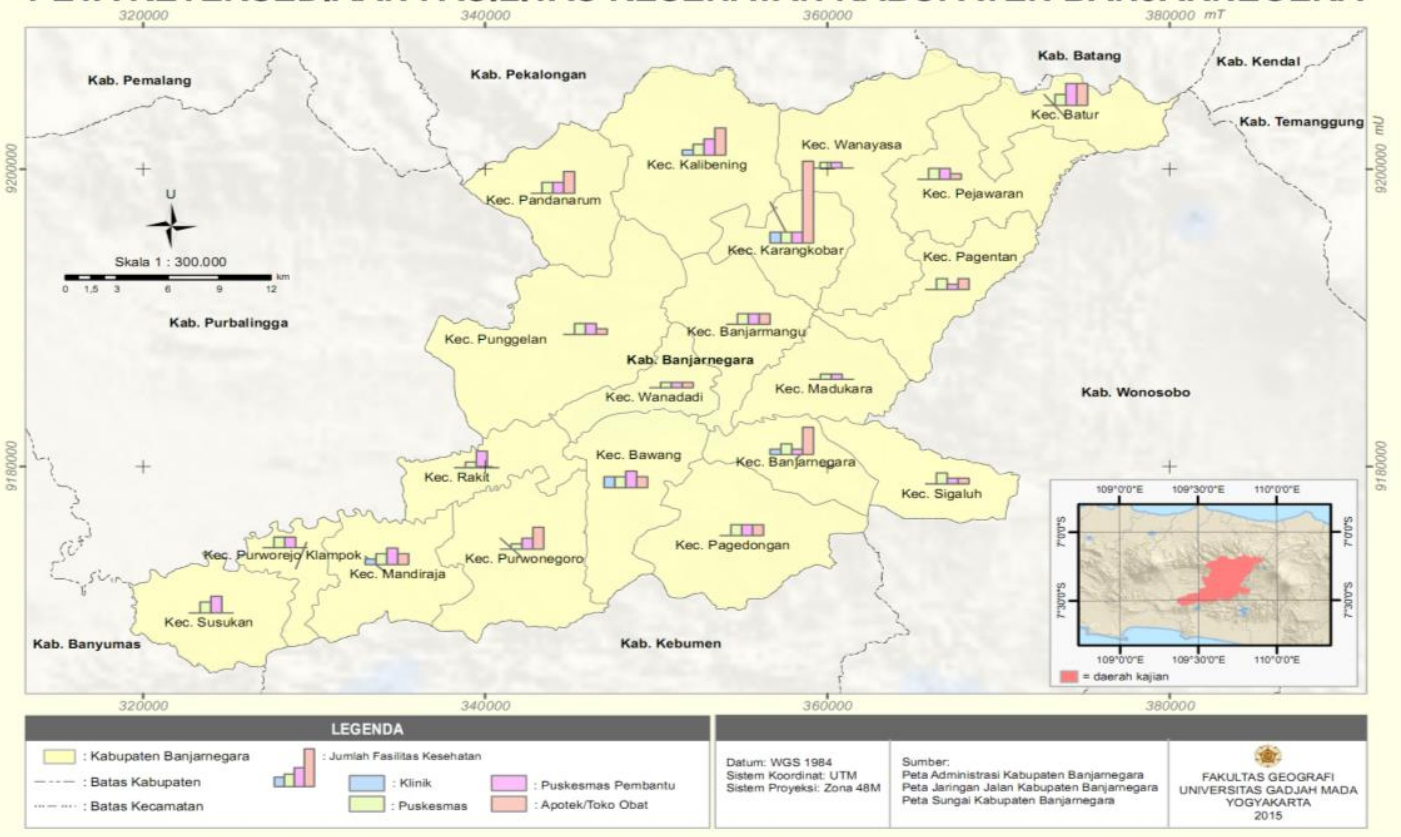

Gambar 2. Ketersediaan Fasilitas Kesehatan Kabupaten Banjarnegara 
Beberapa fasilitas kesehatan pendukung seperti puskesmas keliling, laboratorium, apotek, dan toko obat juga merupakan fasilitas yang penting dalam penyediaan pelayanan kesehatan bagi masyarakat. $\mathrm{Di}$ Kabupaten Banjarnegara secara keseluruhan jumlah fasilitas kesehatan pendukung sudah dapat terpenuhi, hanya saja persebarannya belum merata sehingga beberapa kecamatan yang belum memiliki fasilitas kesehatan pendukung ini perlu diprioritaskan keberadaan fasilitas tersebut. Di Kabupaten Banjarnegara terdapat 13 kecamatan yang sudah memenuhi kebutuhan fasilitas ini, sedangkan kecamatan yang belum memiliki fasilitas pendukung yang berjumlah 7 kecamatan, yaitu: Kecamatan Pagedongan, Rakit, Punggelan, Pagentan, Pejawaran, Wanayasa, dan Pandanarum (lihat Tabel 3).

Tabel 3.

Ketersediaan dan Kebutuhan Fasilitas Kesehatan di Kabupaten Banjarnegara

Tahun 2015

\begin{tabular}{|c|l|c|c|c|c|c|c|c|}
\hline No & $\begin{array}{l}\text { Kecama- } \\
\text { tan }\end{array}$ & $\begin{array}{c}\text { Jumlah } \\
\text { Penduduk } \\
\mathbf{2 0 1 5}\end{array}$ & $\begin{array}{c}\text { Keter- } \\
\text { sediaan } \\
\text { RS }\end{array}$ & $\begin{array}{c}\text { Kebutu } \\
- \text { han } \\
\text { RS }\end{array}$ & $\begin{array}{c}\text { Ket. } \\
\text { RS }\end{array}$ & $\begin{array}{c}\text { Keterse- } \\
\text { diaan } \\
\text { Puskes. }\end{array}$ & $\begin{array}{c}\text { Kebutu- } \\
\text { han } \\
\text { Puskes } \\
\text { mas }\end{array}$ & $\begin{array}{c}\text { Ket. } \\
\text { Puskes } \\
\cdot\end{array}$ \\
\hline \hline 1 & Susukan & 59.621 & 0 & 0 & $\mathrm{~T}$ & 2 & 0 & $\mathrm{~T}$ \\
\hline 2 & $\begin{array}{l}\text { Purwareja } \\
\text { Klampok }\end{array}$ & 46.139 & 1 & 0 & $\mathrm{~T}$ & 2 & 0 & $\mathrm{~T}$ \\
\hline 3 & Mandiraja & 63.835 & 0 & 1 & $\mathrm{~B} \mathrm{~T}$ & 2 & 1 & $\mathrm{~T}$ \\
\hline 4 & $\begin{array}{l}\text { Purwa- } \\
\text { negara }\end{array}$ & 69.401 & 0 & 1 & $\mathrm{~B} \mathrm{~T}$ & 2 & 1 & $\mathrm{~T}$ \\
\hline 5 & Bawang & 52.078 & 1 & 0 & $\mathrm{~T}$ & 2 & 0 & $\mathrm{~T}$ \\
\hline 6 & $\begin{array}{l}\text { Banjar- } \\
\text { negara }\end{array}$ & 57.849 & 1 & 0 & $\mathrm{~T}$ & 2 & 0 & $\mathrm{~T}$ \\
\hline 7 & $\begin{array}{l}\text { Pagedo- } \\
\text { ngan }\end{array}$ & 35.099 & 0 & 0 & $\mathrm{~T}$ & 1 & 0 & $\mathrm{~T}$ \\
\hline 8 & Sigaluh & 29.206 & 0 & 0 & $\mathrm{~T}$ & 2 & 0 & $\mathrm{~T}$ \\
\hline 9 & Madukara & 40.496 & 0 & 0 & $\mathrm{~T}$ & 2 & 0 & $\mathrm{~T}$ \\
\hline 10 & $\begin{array}{l}\text { Banjar- } \\
\text { mangu }\end{array}$ & 39.300 & 0 & 0 & $\mathrm{~T}$ & 2 & 0 & $\mathrm{~T}$ \\
\hline 11 & Wanadadi & 28.440 & 0 & 0 & $\mathrm{~T}$ & 2 & 0 & $\mathrm{~T}$ \\
\hline 12 & Rakit & 49.346 & 0 & 0 & $\mathrm{~T}$ & 2 & 0 & $\mathrm{~T}$ \\
\hline 13 & Punggelan & 69.352 & 0 & 1 & $\mathrm{~B} \mathrm{~T}$ & 2 & 1 & $\mathrm{~T}$ \\
\hline 14 & $\begin{array}{l}\text { Karang- } \\
\text { kobar }\end{array}$ & 27.562 & 0 & 0 & $\mathrm{~T}$ & 1 & 0 & $\mathrm{~T}$ \\
\hline 15 & Pagentan & 35.569 & 0 & 0 & $\mathrm{~T}$ & 2 & 0 & $\mathrm{~T}$ \\
\hline 16 & Pejawaran & 41.205 & 0 & 0 & $\mathrm{~T}$ & 1 & 0 & $\mathrm{~T}$ \\
\hline 17 & Batur & 36.912 & 0 & 0 & $\mathrm{~T}$ & 2 & 0 & $\mathrm{~T}$ \\
\hline 18 & Wanayasa & 44.336 & 0 & 0 & $\mathrm{~T}$ & 2 & 0 & $\mathrm{~T}$ \\
\hline 19 & Kalibening & 43.144 & 0 & 0 & $\mathrm{~T}$ & 1 & 0 & $\mathrm{~T}$ \\
\hline 20 & $\begin{array}{l}\text { Pandan- } \\
\text { arum }\end{array}$ & 21.061 & 0 & 0 & $\mathrm{~T}$ & 1 & 0 & $\mathrm{~T}$ \\
\hline & Jumlah & 889.951 & $\mathbf{3}$ & $\mathbf{7}$ & $\mathrm{B} \mathrm{T}$ & 35 & 7 & $\mathrm{~T}$ \\
\hline
\end{tabular}




\begin{tabular}{|c|c|c|c|c|c|c|c|c|}
\hline No & $\begin{array}{l}\text { Kecama- } \\
\tan \end{array}$ & $\begin{array}{l}\text { Jumlah } \\
\text { Penduduk } \\
2015\end{array}$ & $\begin{array}{c}\text { Keter- } \\
\text { sediaan } \\
\text { Pustu }\end{array}$ & $\begin{array}{c}\text { Kebutu } \\
\text {-han } \\
\text { Pustu }\end{array}$ & $\begin{array}{c}\text { Ket. } \\
\text { Pustu }\end{array}$ & $\begin{array}{c}\text { Keterse- } \\
\text { diaan Fas. } \\
\text { Kes. } \\
\text { Pendukung }\end{array}$ & $\begin{array}{c}\text { Kebutu- } \\
\text { han Fas. } \\
\text { Kes. } \\
\text { Pendu- } \\
\text { kung } \\
\end{array}$ & $\begin{array}{l}\text { Ket. } \\
\text { Fas. } \\
\text { Kes. } \\
\text { Pendu- } \\
\text { kung }\end{array}$ \\
\hline 1 & Susukan & 59.621 & 2 & 2 & $\mathrm{~T}$ & 2 & 2 & $\mathrm{~T}$ \\
\hline 2 & $\begin{array}{l}\text { Purwareja } \\
\text { Klampok }\end{array}$ & 46.139 & 1 & 2 & B T & 5 & 2 & $\mathrm{~T}$ \\
\hline 3 & Mandiraja & 63.835 & 4 & 2 & $\mathrm{~T}$ & 4 & 2 & $\mathrm{~T}$ \\
\hline 4 & $\begin{array}{l}\text { Purwa- } \\
\text { negara }\end{array}$ & 69.401 & 3 & 2 & $\mathrm{~T}$ & 2 & 2 & $\mathrm{~T}$ \\
\hline 5 & Bawang & 52.078 & 3 & 2 & $\mathrm{~T}$ & 5 & 2 & $\mathrm{~T}$ \\
\hline 6 & $\begin{array}{l}\text { Banjar- } \\
\text { negara }\end{array}$ & 57.849 & 2 & 2 & $\mathrm{~T}$ & 15 & 2 & $\mathrm{~T}$ \\
\hline 7 & $\begin{array}{l}\text { Pagedo- } \\
\text { ngan }\end{array}$ & 35.099 & 1 & 1 & $\mathrm{~T}$ & 0 & 1 & B T \\
\hline 8 & Sigaluh & 29.206 & 3 & 1 & $\mathrm{~T}$ & 2 & 1 & $\mathrm{~T}$ \\
\hline 9 & Madukara & 40.496 & 2 & 1 & $\mathrm{~T}$ & 2 & 1 & $\mathrm{~T}$ \\
\hline 10 & $\begin{array}{l}\text { Banjar- } \\
\text { mangu }\end{array}$ & 39.300 & 1 & 1 & $\mathrm{~T}$ & 2 & 1 & $\mathrm{~T}$ \\
\hline 11 & Wanadadi & 28.440 & 2 & 1 & $\mathrm{~T}$ & 4 & 1 & $\mathrm{~T}$ \\
\hline 12 & Rakit & 49.346 & 2 & 2 & $\mathrm{~T}$ & 1 & 2 & B T \\
\hline 13 & Punggelan & 69.352 & 2 & 2 & $\mathrm{~T}$ & 1 & 2 & B T \\
\hline 14 & $\begin{array}{l}\text { Karang- } \\
\text { kobar }\end{array}$ & 27.562 & 2 & 1 & $T$ & 4 & 1 & T \\
\hline 15 & Pagentan & 35.569 & 2 & 1 & $\mathrm{~T}$ & 0 & 1 & B T \\
\hline 16 & Pejawaran & 41.205 & 3 & 1 & $\mathrm{~T}$ & 0 & 1 & B T \\
\hline 17 & Batur & 36.912 & 1 & 1 & $\mathrm{~T}$ & 1 & 1 & $\mathrm{~T}$ \\
\hline 18 & Wanayasa & 44.336 & 3 & 1 & $\mathrm{~T}$ & 0 & 1 & B T \\
\hline 19 & Kalibening & 43.144 & 1 & 1 & $\mathrm{~T}$ & 1 & 1 & $\mathrm{~T}$ \\
\hline 20 & $\begin{array}{l}\text { Pandan- } \\
\text { arum }\end{array}$ & 21.061 & 1 & 1 & $\mathrm{~T}$ & 0 & 1 & B T \\
\hline & Jumlah & 889.951 & 41 & 30 & $\mathbf{T}$ & 51 & 30 & $\mathbf{T}$ \\
\hline
\end{tabular}

Sumber: Hasil pengolahan dan analisis data primer, 2017

\section{Tempat Ibadah}

Tempat peribadatan merupakan fasilitas yang dapat digunakan untuk menunjang kegiatan beragama. Pada fasilitas peribadahan umat islam (masjid, langgar, mushola), standar yang ditetapkan adalah 2.500 penduduk untuk 1 masjid dan 250 penduduk untuk sebuah langgar/musholla. Fasilitas peribadatan umat beragama lainnya, belum ditetapkan standar tertentu mengenai pemenuhan kebutuhan fasilitas ibadah.

Di Kabupaten Banjarnegara total jumlah masjid yang ada mencapai 1.533 masjid (lihat Gambar 3)

Jumlah ini telah memenuhi seluruh standar fasilitas masjid di seluruh kecamatan di kabupaten ini. Sedangkan pada fasilitas langgar/musholla, tidak semua kecamatan memenuhi standar yang telah di tetapkan, diantaranya Kecamatan Susukan, Purwanegara 
Klampok, Banjarnegara, Madukara, Pagentan, Pejawaran, Bantur, Wanayasa, dan Kalibening. Namun kurangnya jumlah fasilitas musholla atau langgar dapat digantikan dengan terpenuhinya jumlah fasilitas masjid yang sudah tersebar pada setiap kecamatan.

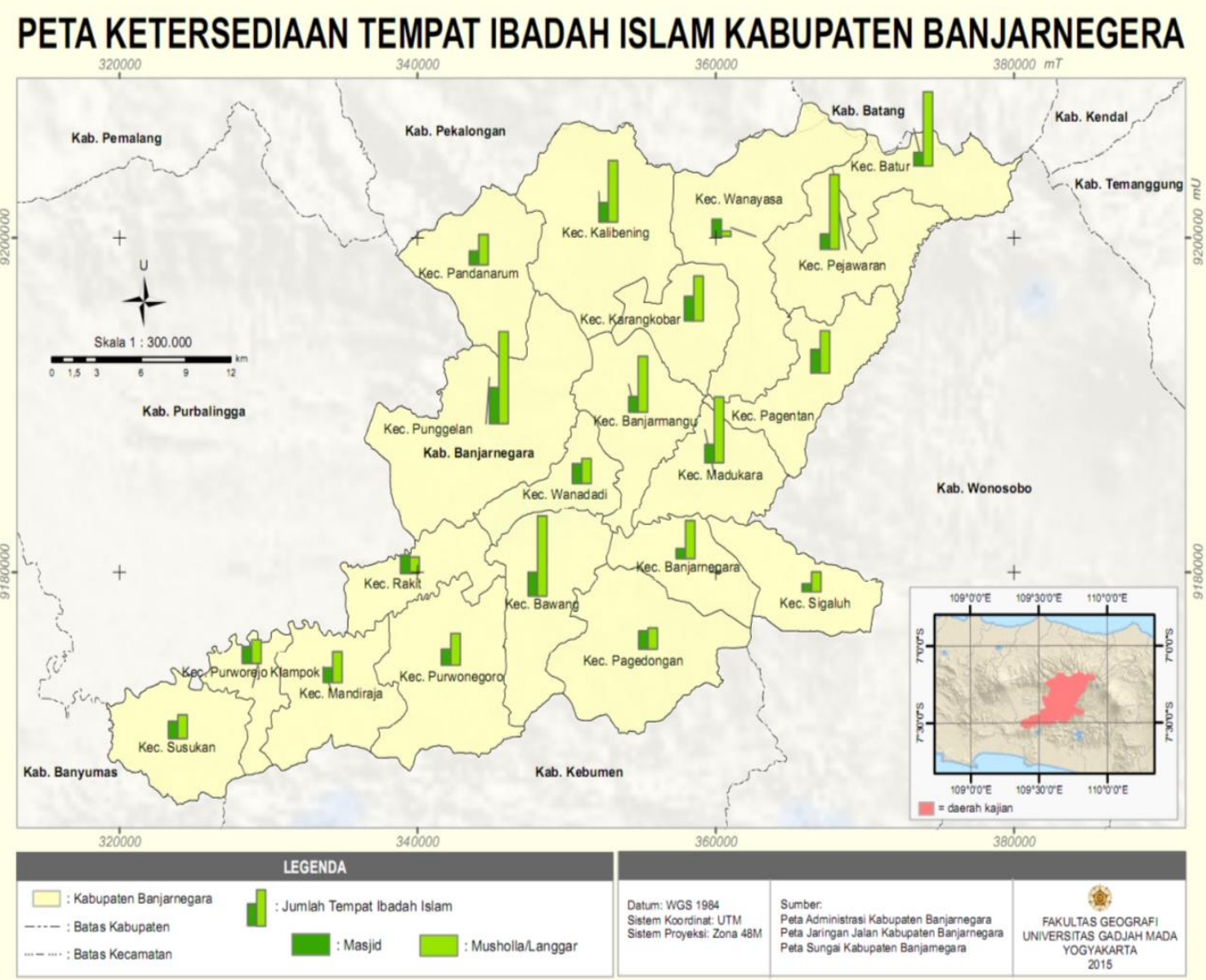

Gambar 3. Ketersediaan Tempat Ibadah Islam Kabupaten Banjarnegara

Tabel 4. Ketersediaan dan Kebutuhan Fasilitas Peribadatan di Kabupaten Banjarnegara Tahun 2015

\begin{tabular}{|c|l|c|c|c|c|}
\hline No & Kecamatan & $\begin{array}{c}\text { Jumlah } \\
\text { Penduduk 2015 }\end{array}$ & $\begin{array}{c}\text { Ketersediaan } \\
\text { Masjid }\end{array}$ & $\begin{array}{c}\text { Kebutuhan } \\
\text { Masjid }\end{array}$ & $\begin{array}{c}\text { Ket. } \\
\text { Fasilitas } \\
\text { Peribadatan }\end{array}$ \\
\hline 1 & Susukan & 59.621 & 67 & 24 & T \\
\hline 2 & $\begin{array}{l}\text { Kurwareja } \\
\text { Klampok }\end{array}$ & 46139 & 44 & 18 & $\mathrm{~T}$ \\
\hline 3 & Mandiraja & 63835 & 57 & 26 & $\mathrm{~T}$ \\
\hline 4 & Purwanegara & 69401 & 100 & 28 & $\mathrm{~T}$ \\
\hline 5 & Bawang & 52078 & 84 & 21 & $\mathrm{~T}$ \\
\hline 6 & Banjarnegara & 57849 & 103 & 23 & $\mathrm{~T}$ \\
\hline
\end{tabular}




\begin{tabular}{|c|l|c|c|c|c|}
7 & Pagedongan & 35099 & 77 & 14 & $\mathrm{~T}$ \\
\hline 8 & Sigaluh & 29206 & 63 & 12 & $\mathrm{~T}$ \\
\hline 9 & Madukara & 40496 & 77 & 16 & $\mathrm{~T}$ \\
\hline 10 & Banjarmangu & 39300 & 101 & 16 & $\mathrm{~T}$ \\
\hline 11 & Wanadadi & 28440 & 59 & 11 & $\mathrm{~T}$ \\
\hline 12 & Rakit & 49346 & 65 & 20 & $\mathrm{~T}$ \\
\hline 13 & Punggelan & 69352 & 152 & 28 & $\mathrm{~T}$ \\
\hline 14 & Karangkobar & 27562 & 68 & 11 & $\mathrm{~T}$ \\
\hline 15 & Pagentan & 35569 & 73 & 14 & $\mathrm{~T}$ \\
\hline 16 & Pejawaran & 41205 & 78 & 16 & $\mathrm{~T}$ \\
\hline 17 & Batur & 36912 & 34 & 15 & $\mathrm{~T}$ \\
\hline 18 & Wanayasa & 44336 & 74 & 18 & $\mathrm{~T}$ \\
\hline 19 & Kalibening & 43144 & 84 & 17 & $\mathrm{~T}$ \\
\hline 20 & Pandanarum & 21061 & 73 & 8 & $\mathrm{~T}$ \\
\hline & Jumlah & $\mathbf{8 8 9 9 5 1}$ & $\mathbf{1 5 3 3}$ & $\mathbf{3 5 6}$ & $\mathbf{T}$ \\
\hline
\end{tabular}

Sumber: Hasil pengolahan dan analisis data primer, 2017

\subsection{Fasilitas Sosial Sebagai Sarana Prasarana Umum Darurat Bencana}

Terdapat berbagai penyedia informasi mengenai bahaya bencana alam, salah satunya yakni lembaga negara yang bertanggung jawab dalam penanggulangan bencana, serta kantor layanan fasilitas publik (yang mengeluarkan data-data dan peta-peta bahaya, risiko dan dampak bencana) (Benson, Twigg \& Rossetto, 2007). Di Indonesia terdapat Lembaga Pemerintah Non Departemen, berada di bawah dan bertanggungjawab langsung kepada Presiden yang dibentuk dalam rangka menjalankan tugas dan fungsi penyelenggaraan penanggulangan bencana, yakni Badan Nasional Penanggulangan Bencana (BNPB). Pada level daerah/regional terdapat Badan Penanggulangan Bencana Daerah (BPBD) untuk melaksanakan tugas dan fungsi penanggulangan bencana di daerah.
Kejadian bencana alam di Kabupaten Banjarnegara didominasi oleh bencana tanah longsor. Meskipun terdapat bencana yang lain, seperti: bencana angin kencang, kebakaran, pohon tumbang, banjir dan rumah roboh. Dalam periode waktu sebulan di tahun 2017 ini wilayah Kabupaten Banjarnegara dilanda 40 kejadian bencana alam. Berdasarkan BPPD Banjarnegara kejadian tanah longsor terjadi hampir merata baik di pegunungan utara maupun selatan. Wilayah pegunungan utara yang mengalami longsor tersebar di Kecamatan Banjarmangu, Madukara, Pejawaran, Wanayasa, Pagentan, Pandanarum dan Punggelan. Sedang kecamatan di pegunungan utara yang jadi pusat titik longsor tersebar di Kecamatan Susukan, Mandiraja, Purwanegara dan Pagedongan (Aziz, 2017).

Kejadian bencana alam tanah longsor tahun 2014 merupakan bencana 
dengan jumlah pengungsi terbanyak setelah kejadian 1955. Pada tahun 2014 tercatat 1.742 orang pengungsi dari mulai dewasa hingga anak-anak. Longsor yang terjadi Jumat sore (12 Desember 2014) di Dusun Jemblung, Desa Sampang, Kecamatan Karangkobar mengakibatkan sebanyak 105 rumah tertimbun longsor, satu masjid dan sungai sepanjang $1 \mathrm{~km}$ rata dengan tanah, sawah seluas $8 \mathrm{Ha}$ dan kebun palawija seluas $5 \mathrm{Ha}$ juga rusak parah. Pada kejadian ini warga mengungsi di 17 posko pengungsian dan ke rumah keluarga di luar area bencana. Beberapa tempat yang menjadi posko pengungsian ialah puskesmas, tempat ibadah, sekolah, dan tenda posko yang dibangun petugas. (Suriyanto, 2014).

Berdasarkan fakta dan peristiwa yang terjadi seperti dijabarkan di atas, fasilitas sosial yang dapat mendukung saat kondisi darurat bencana adalah fasilitas yang diadakan oleh pemerintah atau pihak swasta yang dapat dimanfaatkan oleh masyarakat umum di lingkungan sekitarnya. Beberapa contoh fasilitas tersebut adalah puskesmas, klinik, sekolah, tempat ibadah, tempat olahraga, pasar, taman/ruang terbuka, dan ruang serbaguna. Fasilitas-fasilitas sosial seperti sekolah, balai desa, gedung serbaguna, dan tempat ibadah sering dijadikan sebagai lokasi pengungsian ketika terjadi bencana.

\section{Fungsi Fasilitas Pendidikan dalam}

Situasi Darurat Bencana

Fasilitas pendidikan sangat penting bagi keberlangsungan regenerasi bangsa. Sekolah sebagai ruang publik menjadi sangat penting dalam situasi darurat bencana. Pada kondisi bencana, fasilitas pendidikan dapat bermanfaat untuk berbagai hal, salah satunya untuk lokasi titik kumpul evakuasi atau sarana penampungan sementara. Secara umum sekolah menempati lahan yang relatif luas dengan ruang kelas dan halaman yang memungkinkan untuk berkumpul.

Beberapa kasus yang terjadi di wilayah Indonesia, saat terjadi banjir pemerintah menghimbau masyarakat untuk mengungsi di sekolah hingga banjir surut. Pada tahun 2010, Pemerintah Kabupaten Sleman menyiapkan fasilitas-fasilitas sosial sebagai lokasi pengungsian. Dua puluh (20) lokasi pengungsian berupa balai desa dan gedung sekolah dialihfungsikan menjadi tempat pengungsian. Hal ini merupakan upaya darurat dalam mengantisipasi kemungkinan yang dapat terjadi akibat aktivitas Gunung Merapi (Anggardha, 2010).

Di Kabupaten Banjarnegara sendiri, pada tahun 2016 peristiwa longsor di Desa Clapar menyebabkan sebanyak 250 warga dari 83 kepala keluarga (KK) mengungsi di gedung TK Pertiwi, Clapar, Madukara (Parwito, 2016). Sumber lain menyebutkan bahwa sebanyak 158 jiwa warga RT 3-5 RW 1 mengungsi ke SD Negeri 2 Clapar, Madukara (Maharani, 2016). Berdasarkan fakta tersebut, peran fasilitas pendidikan (sekolah) dalam kondisi darurat bencana sangat menunjang untuk evakuasi dan tempat pengungsian korban bencana.

\begin{tabular}{llr} 
Fasilitas-fasilitas & \multicolumn{1}{c}{ sosial } & yang \\
difungsikan & sebagai & lokasi \\
penampungan & pengungsi & harus
\end{tabular}


memenuhi beberapa kondisi, antara lain berupa bangunan permanen/ bangunan darurat, kapasitas cukup besar, tersedia air bersih, terdapat sarana MCK, terdapat tempat pembuangan sampah, serta memiliki penerangan yang cukup (Departemen Kesehatan RI, 2007).

Fungsi Balai Pertemuan dalam Situasi Darurat Bencana

Fasilitas publik menjadi salah satu bagian yang penting dalam kondisi darurat bencana yang dapat dimanfaatkan dalam penyelenggaraan penanggulangan bencana. Pada kondisi tersebut penyelamatan dan evakuasi masyarakat yang terkena bencana menjadi hal yang vital. Dalam kondisi darurat/tanggap bencana diperlukan pembentukan pos komando tanggap darurat bencana.

Balai Pertemuan merupakan salah satu fasilitas publik yang dapat digunakan dalam situasi tanggap darurat bencana. Beberapa fungsi balai pertemuan diantaranya sebagai lokasi evakuasi dan pos komando tanggap darurat bencana, hal tersebut diatur dalam Peraturan Kepala Badan Nasional Penanggulangan Bencana Nomor 14 Tahun 2010. Adapun beberapa syarat yang harus dipenuhi oleh sebuah bangunan untuk dijadikan sebagai pos komando tanggap darurat bencana diantaranya: bangunan harus mudah diakses oleh berbagai pihak yang terlibat dalam kegiatan tanggap darurat bencana, aman dan terbebas dari ancaman bencana, memiliki lahan parkir yang memadai, dan memiliki luas lahan sekurang-kurangnya $500 \quad \mathrm{~m}^{2}$. Keberadaan balai pertemuan dapat mempermudah tim yang berfungsi sebagai pusat komando operasi tanggap darurat bencana, untuk mengkoordinasikan, mengendalikan, memantau dan mengevaiuasi pelaksanaan tanggap darurat bencana.

Fungsi Fasilitas Kesehatan dalam

Situasi Darurat Bencana

Fasilitas kesehatan merupakan hal yang vital dalam kondisi tanggap/darurat bencana. Pada kondisi ini, diperlukan perlindungan dan pelayanan terhadap korban bencana secara cepat dan tepat. Dalam kondisi tanggap bencana di tingkat kabupaten atau kota. fasilitas kesehatan dan instansi berfungsi sebagai koordinator pembagian obat dan pelayanan kesehatan. Di dalam Pedoman Teknis Penanggulangan Krisis Kesehatan Akibat Bencana tahun 2007 Departemen Kesehatan RI menyampaikan bahwa setiap fasilitas kesehatan terbagi atas beberapa tahapan dan tugas dalam pengaturan dan pendistribusian obat dan pembekalan kesehatan, diantaranya:

1. Posko kesehatan langsung meminta obat dan pembekalan kesehatan kepada Dinas Kesehatan setempat.

2. Obat dan pembekalan kesehatan yang tersedia di Puskesmas Pembantu (Pustu) dan Puskesmas dapat langsung dimanfaatkan untuk melayani korban bencana, bila terjadi kekurangan Puskesmas ataupun Pustu dapat langsung meminta tambahan ke Dinkes $\mathrm{Ka} / \mathrm{Kota}$ (Instalasi Farmasi $\mathrm{Kab} / \mathrm{Kota})$

3. Dinkes Kab/Kota (Instalasi Farmasi Kab/Kota) menyiapkan obat dan pembekalan kesehatan 
selama 24 jam untuk seluruh sarana kesehatan yang melayani korban bencana baik di Puskesmas, pos kesehatan, RSU, Sarana Pelayanan Kesehatan TNI dan POLRI maupun Swasta.

4. Dinkes Provinsi dan/atau Depkes c.q Pusat Penanggulangan Krisis yang berkoordinasi dengan Ditjen Binfar dan Alkes berfungsi sebagai penyedia obat apabila mengalami kekurangan suplai.

\section{Penutup}

Sarana prasarana umum berfungsi untuk mengembangkan kehidupan dan penghidupan keluarga serta mengembangkan kegiatan bermasyarakat terkait sosial, budaya dan ekonomi. Kegiatan masyarakat terkait sosial dapat dilakukan di gedung pertemuan warga maupun tempat ibadah, seperti kegiatan rapat warga, pertemuan PKK, LKMD, sosialisasi kegiatan pemerintah, maupun kegiatan keagamaan. Terkait kegiatan budaya juga dapat dilakukan di gedung pertemuan atau balai, seperti upacara peringatan budaya, kesenian warga (tarian, musik, dan lain-lain), juga pertunjukan seni budaya warga. Kegiatan ekonomi warga dapat dilakukan pada fasilitas ekonomi seperti warung, toko, pasar, hingga bank.

Evaluasi ketersediaan dan kebutuhan fasilitas sosial penting dilakukan guna mendukung pengembangan wilayah. Fungsi lain dari fasilitas publik menjadi penting terutama dalam kondisi darurat bencana yang dapat dimanfaatkan dalam penyelenggaraan penanggulangan bencana. Pada kondisi tersebut penyelamatan dan evakuasi masyarakat yang terkena bencana menjadi hal yang vital.

Hasil dari penelitian ini adalah analisis ketersediaan dan kebutuhan fasilitas sosial sebagai sarana prasarana umum di Kabupaten Banjarnegara sesuai dengan daya layan dan standar nasional yang ditetapkan menunjukkan bahwa fasilitas pendidikan tingkat TK dan SD masih dapat memenuhi kebutuhan penduduk terhadap fasilitas ini, sedangkan fasilitas pendidikan tingkat SMP dan SMA masih memerlukan penambahan. Kebutuhan penduduk terhadap fasilitas kesehatan dapat dipenuhi oleh puskesmas, puskesmas pembantu, dan fasilitas kesehatan pendukung lainnya (Puskesmas keliling, laboratorium, apotek, dan toko obat). Fasilitas peribadatan berupa masjid sudah tersebar merata dan terpenuhi pada setiap kecamatan di Kabupaten Banjarnegara. Dengan analisis daya layan dapat dilakukan evaluasi ketersediaan dan kebutuhan fasilitas sosial berbasis wilayah serta dapat menjadi bahan masukan dalam perencanaan pengembangan wilayah ke depan, khususnya perencanaan fasilitas sosial.

\section{Daftar Pustaka}

Aziz, A. (2017). Sebulan Terjadi 40 Bencana, Banjarnegara Tetapkan Masa Darurat. Diakses November 2017, dari https://www.merdeka.com/peristiwa/.

Ardila, R. (2012). Analisis Pengembangan Pusat Pertumbuhan Ekonomi di Kabupaten Banjarnegara. Economics 
Development Analysis Journal, 1 (2), 1-9.

Benson, Charlotte, John Twigg \&

Tiziana Rossetto. (2007). Perangkat untuk Mengarusutamakan

Pengurangan Risiko Bencana: Catatan Panduan bagi LembagaLembaga yang Bergerak dalam Bidang Pembangunan. Switzerland: ProVention Consortium Secretariat.

Dharmasanti, R. (2016). Sarana Prasarana Permukiman Berdasarkan Sistem Perkotaan di Kabupaten Banjarnegara. Skripsi (tidak diterbitkan). Fakultas Geografi UGM, Yogyakarta.

Humas DPRD Banjarnegara. (2014). Banjarnegara Terkepung Bencana. Diakses Desember 2016, dari http://dprdbanjarnegara.go.id/category/berita/.

Kementerian Pekerjaan Umum. 2007. Peraturan Menteri PU No. 41/PRT/M/2007 tentang Pedoman Kriteria Teknis Kawasan Budi Daya. Jakarta.

Maharani, E. (2016). 158 Korban Longsor Banjarnegara Masih di Pengungsian. Diakses November 2016, dari http://nasional.republika.co.id/ $\mathrm{kanal} / \mathrm{news} /$ nasional.

Parwito. (2016). Bayi di Posko Pengungsian Longsor Banjarnegara Membutuhkan Popok. Diakses November 2017, dari https://www.merdeka.com/peristiwa/.

Sadali, Mohammad Isnaini. (2014). Trend Perkembangan Penduduk dan Implikasinya Terhadap Kebutuhan RTH (Ruang Terbuka Hijau) di D.I. Yogyakarta. Di dalam Prosiding Pertemuan IImiah Ikatan Geograf Indonesia (IGI). Hastuti et al. (Eds). hlm 366-379. Yogyakarta: Jurusan Pendidikan Geografi UNY.

Soemarwoto, O. (1998). Analisis Dampak Lingkungan. Yogyakarta: Gadjah Mada University Press.

SNI 03-1733-2004. (2004). Tata Cara Perencanaan Lingkungan Perumahan di Perkotaan. Jakarta: Kementerian Pekerjaan Umum.

Suarna, I. W. (2013). Aplikasi Geografi dalam Penanganan Kebencanaan Lingkungan di Indonesia. Media Komunikasi Geografi, 14(1).

Suriyanto. (2014). Pengungsi Longsor Banjarnegara Capai 1.742 Jiwa. Diakses Oktober 2015, dari https://www.cnnindonesia.com/nasio nal/20141215082747-20-18106/.

Yunus, H. S. (2002). Struktur Tata Ruang Kota. Yogyakarta: Pustaka Pelajar.

Anggardha, A. 2010. Pemkab Sleman Siapkan 20 Lokasi Pengungsian. Diakses Oktober 2015, dari news.viva. co.id/news/read/184513pemkab-sleman-siapkan-20-lokasipengungsian.

Departemen Kesehatan RI. (2007). Tentang Pedoman Teknis Penanggulangan Krisis Kesehatan akibat Bencana. Jakarta: Departemen Kesehatan RI. 